\title{
Balkanologie
}

Balkanologie Revue d'études pluridisciplinaires

Vol. IX, n' 1-2 | 2005

Volume IX Numéro 1-2

\section{Bernard (Antonia), éd., La Slovénie et l'Europe. Contributions à la connaissance de la Slovénie actuelle}

Paris : l'Harmattan, 2005, 170 p.

\section{Diane Masson}

\section{OpenEdition}

\section{Journals}

Édition électronique

URL : http://journals.openedition.org/balkanologie/2017

DOI : 10.4000/balkanologie.2017

ISSN : 1965-0582

Éditeur

Association française d'études sur les Balkans (Afebalk)

Édition imprimée

Date de publication : 1 décembre 2005

ISSN : 1279-7952

\section{Référence électronique}

Diane Masson, «Bernard (Antonia), éd. La Slovénie et l'Europe. Contributions à la connaissance de la Slovénie actuelle », Balkanologie [En ligne], Vol. IX, n 1-2 | 2005, mis en ligne le 14 janvier 2010, consulté le 17 décembre 2020. URL : http://journals.openedition.org/balkanologie/2017 ; DOI : https://doi.org/ 10.4000/balkanologie.2017

Ce document a été généré automatiquement le 17 décembre 2020.

(C) Tous droits réservés 


\title{
Bernard (Antonia), éd., La Slovénie et l'Europe. Contributions à la connaissance de la Slovénie actuelle
}

Paris : l'Harmattan, 2005, $170 \mathrm{p}$.

\author{
Diane Masson
}

\section{RÉFÉRENCE}

Bernard (Antonia), éd., La Slovénie et l'Europe. Contributions à la connaissance de la Slovénie actuelle, Paris : l'Harmattan, 2005, $170 \mathrm{p}$.

1 Les ouvrages en français consacrés à la Slovénie sont trop rares et chaque nouvelle parution sur cette petite république ex-yougoslave apparaitrait presque comme un événement bibliographique. Spécialiste de la Slovénie et maître de conférences à l'INALCO, Antonia Bernard s'entoure ici de onze contributeurs de choix pour dresser un portait de ce pays aujourd'hui. Membre de l'UE et de l'OTAN, la Slovénie entend occuper une véritable place sur la scène internationale, et joue notamment un rôle moteur dans les Balkans occidentaux. Malgré son appartenance aux institutions euroatlantiques, la Slovénie demeure, d'une part, encore méconnue en France mais elle jouit, d'autre part, d'une étiquette de «bon élève » parmi les nouveaux États membres. Pourtant, derrière cette imagée policée, existent aussi des difficultés inhérentes à toute transition à la démocratie, des complexes de petite nation, des dilemmes, des choix parfois peu aisés en terme de politique étrangère.

2 L'exemple du passé « yougoslave », depuis la création du Royaume des Serbes, Croates et Slovènes en 1918, jusqu'à la Fédération titiste, brutalement rejeté au moment l'indépendance en 1991, est cependant loin d'être exempt d'aspects positifs, comme le souligne l'historien Peter Vodopivec dans sa contribution. Ainsi, "la Slovénie entre dans l'Union européenne avec sa tradition de fédéralisme et avec l'expérience de la vie en communauté à plusieurs ethnies et à plusieurs cultures » (p. 90). Cette connaissance 
des peuples et de leurs «mentalités » offre, par conséquent, aujourd'hui une légitimité à la Slovénie pour ses actions remarquées au sein de l'ancien espace yougoslave, et sa participation aux structures ci-vilo-militaires sur place, au Kosovo et en BosnieHerzégovine notamment.

3 À partir de 1991 pourtant, les débuts de sa construction en tant qu'État indépendant et souverain n'ont pas été aisés. Paul Garde et Bernard Lory mettent en avant deux point importants et problématiques dans le positionnement de la Slovénie : la diplomatie et l'espace géographique. En découlent des hésitations et le désir d'être à la fois européen et atlantiste de la part des autorités Slovènes, alors que la population, elle, marque clairement son choix en faveur de l'Europe au moment du double référendum sur l'adhésion. De même, la construction de l'identité nationale, toujours complexe, est principalement articulée, pour le cas Slovène, dans le rapport à la langue et à la culture : "seule la culture, patiemment élaborée et entretenue autour de leur langue permit aux Slovènes de former peu à peu une entité nationale et finalement étatique » (Antonia Bernard citée par Sasa Horvat, p. 113).

4 On peut, tout en se félicitant vivement d'une telle parution, regretter peut-être, après lecture de l'ensemble des contributions, l'absence d'un réel fil conducteur entre ces dernières. Néanmoins, un des objectifs de cet ouvrage collectif, à savoir «servir de premier guide " sur la Slovénie, est certainement atteint. Il reste à espérer que «l'incitation à d'autres ouvrages plus vastes consacrés à la Slovénie européenne contemporaine » le sera également... 